\title{
RESUMOS/ABSTRACTS*
}

\section{PENSAR O BRASIL}

Por ocasião dos 25 anos de existência do Centro de Estudos de Cultura Contemporânea - CEDEC um grupo de intelectuais convidados discute três dimensões do problema de pensar o Brasil. São elas: por que pensar, como se pensa e como pensar. As exposições e debates cobrem a totalidade deste número da revista.

\section{BRAZILIAN THROUGHT ON BRAZIL}

On the 25th anniversary of the Center for Contemporary Cultural Studies - CEDEC, a group of invited intellectuals discuss three dimensions of the problem of how Brazilian throught faces Brazil as its object. They are: why to think, how it has been thought, and how to think.

* Neste como em todos os números anteriores de Lua Nova-Revista de Cultura e Política os resumos/abstracts são de responsabilidade editorial. 